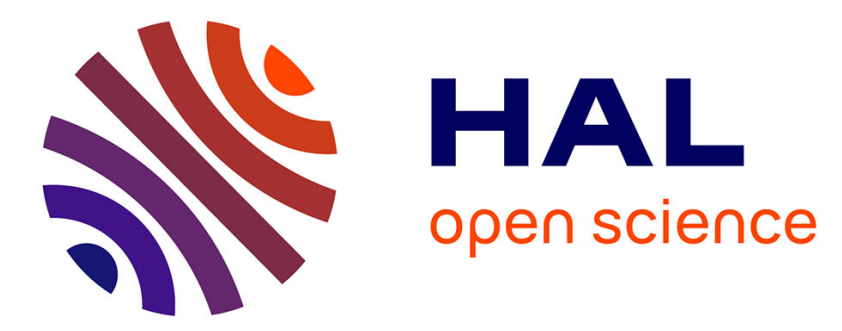

\title{
Spatial and sex differences in mercury contamination of skuas in the Southern Ocean
}

\author{
William F Mills, Andres E Ibañez, Paco Bustamante, Ana P B Carneiro, \\ Stuart Bearhop, Yves Cherel, Rocío Mariano-Jelicich, Rona a R Mcgill, Diego \\ Montalti, Stephen C Votier, et al.
}

\section{To cite this version:}

William F Mills, Andres E Ibañez, Paco Bustamante, Ana P B Carneiro, Stuart Bearhop, et al.. Spatial and sex differences in mercury contamination of skuas in the Southern Ocean. Environmental Pollution, 2022, 297, pp.118841. 10.1016/j.envpol.2022.118841 . hal-03523303

\section{HAL Id: hal-03523303 https://hal.science/hal-03523303}

Submitted on 12 Jan 2022

HAL is a multi-disciplinary open access archive for the deposit and dissemination of scientific research documents, whether they are published or not. The documents may come from teaching and research institutions in France or abroad, or from public or private research centers.
L'archive ouverte pluridisciplinaire HAL, est destinée au dépôt et à la diffusion de documents scientifiques de niveau recherche, publiés ou non, émanant des établissements d'enseignement et de recherche français ou étrangers, des laboratoires publics ou privés. 


\section{Spatial and sex differences in mercury contamination of skuas in the \\ Southern Ocean}

William F. Mills, ${ }^{\mathrm{a}, \mathrm{b}, \dagger}$ Andrés E. Ibañez, ${ }^{\mathrm{c}}$ Paco Bustamante, ${ }^{\mathrm{d}, \mathrm{e}}$ Ana P. B. Carneiro, ${ }^{\mathrm{f}}$ Stuart

Bearhop, ${ }^{\mathrm{b}}$ Yves Cherel, ${ }^{\mathrm{g}}$ Rocío Mariano-Jelicich, ${ }^{\mathrm{h}}$ Rona A. R. McGill, ${ }^{\mathrm{i}}$ Diego Montalti, ${ }^{\mathrm{c}, \mathrm{j}}$

Stephen C. Votier, ${ }^{\mathrm{k}}$ Richard A. Phillips ${ }^{\mathrm{a}}$

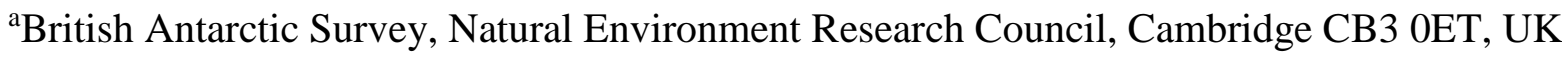

${ }^{\mathrm{b}}$ Centre for Ecology and Conservation, University of Exeter, Cornwall TR10 9EZ, UK

'Sección Ornitología, Div. Zool. Vert., Museo de La Plata (FCNyM-UNLP, CONICET), Museo de la Plata, Paseo del Bosque s/n, B1900FWA-La Plata, Buenos Aires, Argentina

${ }^{\mathrm{d}}$ Littoral Environnement et Sociétés (LIENSs), UMR 7266, CNRS-La Rochelle Université, 2 rue Olympe de Gouges, 17000 La Rochelle, France

eInstitut Universitaire de France (IUF), 1 rue Descartes, 75005 Paris, France

fBirdLife International, The David Attenborough Building, Pembroke St, Cambridge CB2 3QZ, UK

g'Centre d'Etudes Biologiques de Chizé (CEBC), UMR 7372 du CNRS-La Rochelle Université, 79360 Villiers-en-Bois, France

${ }^{\mathrm{h}}$ Instituto de Investigaciones Marinas y Costeras (IIMyC), UNMdP-CONICET, Universidad Nacional de Mar del Plata, Mar del Plata, Argentina

iStable Isotope Ecology Lab, Natural Environment Isotope Facility, Scottish Universities Environmental Research Centre, East Kilbride G75 0QF, UK

jInstituto Antartico Argentino, 25 de Mayo 1143, (B1650HMK) San Martin, Buenos Aires, Argentina 
${ }^{\mathrm{k}}$ Lyell Centre, Heriot-Watt University, Edinburgh, UK

${ }^{\dagger}$ Corresponding author. William F. Mills (ORCID: 0000-0001-7170-5794)

Email:wilmil23@bas.ac.uk

Address: British Antarctic Survey,

Natural Environment Research Council,

Cambridge CB3 OET, UK

\section{Highlights}

- Blood total mercury (THg) concentrations were measured in skuas across a latitudinal gradient.

- Hg contamination increased from the Antarctic Peninsula to South Georgia.

- Blood THg concentrations showed a weak positive correlation with $\delta^{15} \mathrm{~N}$.

- Male brown skuas showed higher Hg contamination than females.

Abstract: Antarctic marine ecosystems are often considered to be pristine environments, yet wildlife in the polar regions may still be exposed to high levels of environmental contaminants. Here, we measured total mercury ( $\mathrm{THg}$ ) concentrations in blood samples from adult brown skuas Stercorarius antarcticus lonnbergi $(n=82)$ from three breeding colonies south of the Antarctic Polar Front in the Southern Ocean (southwest Atlantic region): (i) Bahía Esperanza/Hope Bay, Antarctic Peninsula; (ii) Signy Island, South Orkney Islands; and, (iii) Bird Island, South Georgia. Blood THg concentrations increased from the Antarctic Peninsula towards the Antarctic Polar Front, such that $\mathrm{Hg}$ contamination was lowest at Bahía Esperanza/Hope Bay (mean $\pm \mathrm{SD}, 0.95 \pm 0.45 \mu \mathrm{g} \mathrm{g}^{-1} \mathrm{dw}$ ), intermediate at Signy Island (3.42 \pm $\left.2.29 \mu \mathrm{g} \mathrm{g}^{-1} \mathrm{dw}\right)$ and highest at Bird Island $\left(4.47 \pm 1.10 \mu \mathrm{g} \mathrm{g}^{-1} \mathrm{dw}\right)$. Blood THg concentrations also showed a weak positive correlation with $\delta^{15} \mathrm{~N}$ values, likely reflecting the biomagnification process. Males had higher $\mathrm{Hg}$ burdens than females, which may reflect deposition of $\mathrm{Hg}$ into eggs by females or potentially differences in their trophic ecology. These data provide important insights into intraspecific variation in contamination and the geographic transfer of $\mathrm{Hg}$ to seabirds in the Southern Ocean.

Keywords: seabird; pollutants; metals; stable isotopes; Antarctica; Southern Hemisphere 


\section{Introduction}

Mercury $(\mathrm{Hg})$ is a pervasive environmental contaminant of major concern for both humans and wildlife. Hg derives from both natural and anthropogenic sources; however, human activities (e.g., coal burning, artisanal and small-scale gold mining) have increased the global $\mathrm{Hg}$ pool (Eagles-Smith et al., 2018; UN Environment, 2019). The gaseous, elemental form of $\mathrm{Hg}\left(\mathrm{Hg}^{0}\right)$ can travel long distances via atmospheric transport to remote locations that are isolated from major emission sources, including the Antarctic (Fitzgerald et al., 1998; Driscoll et al., 2013).

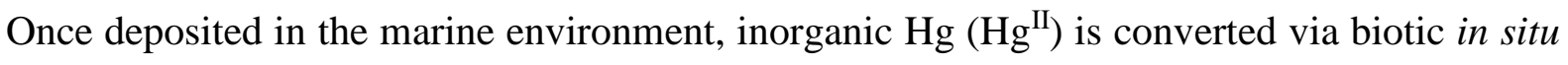
methylation to the more toxic form, methyl- $\mathrm{Hg}\left(\mathrm{MeHg},\left[\mathrm{CH}_{3} \mathrm{Hg}\right]^{+}\right)$, which, once assimilated, bioaccumulates within marine organisms (i.e., concentrations increase within the body over time) and biomagnifies through marine food webs from lower to higher trophic levels (Bargagli et al., 1998; Blum et al., 2013; Seco et al., 2021). Long-lived, upper trophic level predators, such as many seabirds, are potentially exposed to high levels of $\mathrm{Hg}$ through their diets (Cherel et al., 2018).

Seabirds are effective bioindicators of $\mathrm{Hg}$ contamination in marine ecosystems (Monteiro and Furness, 1995; Monteiro et al., 1996; Carravieri et al., 2016). Hg contamination may also negatively impact aspects of seabird behaviour, physiology and development, and can have short- or long-term fitness consequences (Goutte et al., 2014; Ackerman et al., 2016; Mills et al., 2020). Studies of seabird communities in the Southern Ocean, from the Antarctic continent to the subtropics, have demonstrated extensive interspecific variation in $\mathrm{Hg}$ contamination (Anderson et al., 2009a; Carravieri et al., 2014a; Becker et al., 2016; Polito et al., 2016). Hg contamination of seabirds also often differs among conspecifics, and this variation may be driven by factors such as age, sex, breeding status and trophic ecology (Bearhop et al., 2000a; Polito et al., 2016; Mills et al., 2020). Moreover, several studies, mostly undertaken in the Indian Ocean sector of the Southern Ocean, have demonstrated that $\mathrm{Hg}$ contamination is lower for seabirds feeding in Antarctic compared to sub-Antarctic and subtropical waters (Carravieri et al., 2014b, 2016, 2017, 2020; Cherel et al., 2018; Mills et al., 2020; Renedo et al., 2020).

Stable isotope analysis is a well-established method for studying the trophic ecology of seabirds (Cherel et al., 2000; Phillips et al., 2009, 2011). Stable isotope ratios of carbon $\left({ }^{13} \mathrm{C} /{ }^{12} \mathrm{C}\right.$, expressed as $\left.\delta^{13} \mathrm{C}\right)$ and nitrogen $\left({ }^{15} \mathrm{~N} /{ }^{14} \mathrm{~N}, \delta^{15} \mathrm{~N}\right)$ offer powerful alternatives to conventional diet studies (e.g., analyses of regurgitates or pellets), as stable isotope ratios of seabird tissues (e.g., blood) reflect those of their prey in a predictable way (Peterson and Fry, 
1987; Hobson and Clark, 1992; Bearhop et al., 2002; Inger and Bearhop, 2008). $\delta^{15} \mathrm{~N}$ values increase in a stepwise manner by $\sim 3-5 \%$ at each trophic level, whereas $\delta^{13} \mathrm{C}$ values increase less with trophic level ( 0.5-1\%) but can be used to infer foraging habitat (Peterson and Fry, 1987; Hobson and Clark, 1992; Bearhop et al., 2002; Cherel and Hobson, 2007; Phillips et al., 2011). In the marine environment, this includes the relative reliance on an inshore vs. offshore, benthic vs. pelagic diet, and latitude or water mass where a gradient exists, such as in the Southern Ocean (Cherel and Hobson, 2007; Jaeger et al., 2010; Phillips et al., 2009; Quillfeldt et al., 2005, 2010; St John Glew et al., 2021). $\delta^{15} \mathrm{~N}$ values in seabird tissues may also reflect spatial variation in baselines (Elliott et al., 2021). Stable isotope ratios measured in seabird blood samples are appropriate for examining the relationships between $\mathrm{Hg}$ contamination and trophic ecology, owing to the broadly similar timeframe for integration into the blood system (Bond, 2010; Albert et al., 2019).

This study focuses on $\mathrm{Hg}$ contamination of brown skuas Stercorarius antarcticus lonnbergi from three breeding colonies spanning a large latitudinal gradient in the Southern Ocean (southwest Atlantic region), from the Antarctic Peninsula to South Georgia. Brown skuas are opportunistic predators and scavengers in both marine and terrestrial environments, and use a wide variety of feeding methods including aerial and terrestrial hunting, fishing and kleptoparasitism (Furness, 1987; Phillips et al., 2004; Anderson et al., 2009b; Carneiro et al., 2014). Brown skua diets are variable among populations, for instance, in our study region, the reliance on penguin prey decreases from the Antarctic continent towards South Georgia (Burton, 1968; Reinhardt et al., 2000; Phillips et al., 2004; Anderson et al., 2009b; Graña Grilli and Montalti, 2015; Borghello et al., 2019). Brown skuas also show reversed sexual size dimorphism, with females being significantly larger and heavier than males (Phillips et al., 2002), and $\mathrm{Hg}$ burdens are often high in this species owing to their high trophic position (Goutte et al., 2014; Carravieri et al., 2017; Seco et al., 2021). Here, our aim was to analyse how $\mathrm{Hg}$ contamination of brown skuas varies among breeding colonies located at different latitudes, between sexes and, using bulk stable isotope ratios as proxies, in relation to trophic ecology. We make the following a priori predictions: (i) $\mathrm{Hg}$ contamination will increase from the Antarctic Peninsula to lower-latitude breeding colonies; (ii) $\mathrm{Hg}$ contamination will be positively correlated with blood $\delta^{15} \mathrm{~N}$ values, reflecting the biomagnification process; and (iii) females will show lower levels of $\mathrm{Hg}$ contamination than males, potentially reflecting deposition of $\mathrm{Hg}$ into eggs (Robinson et al., 2012). Baseline data on $\mathrm{Hg}$ contamination is especially important for this species, given the detrimental consequences of high $\mathrm{Hg}$ burdens for breeding success elsewhere in the Southern Ocean (Goutte et al., 2014). 


\section{Materials and methods}

\subsection{Study area and sample collection}

Fielwork was undertaken at three brown skua breeding colonies spanning a latitudinal gradient south of the Antarctic Polar Front (APF) in the Southern Ocean (southwest Atlantic region): (i) Bahía Esperanza/Hope Bay, Antarctic Peninsula $\left(63^{\circ} 24^{\prime} \mathrm{S}, \quad 57^{\circ} 01^{\prime} \mathrm{W}\right)$ in

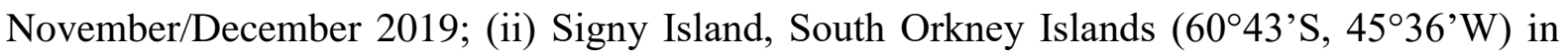

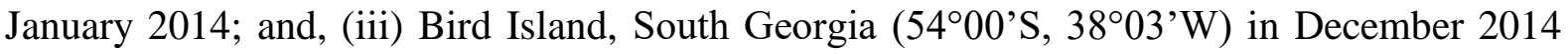
(Fig. 1). At each breeding colony, blood samples were obtained during the mid to late incubation periods from either the tarsal or brachial vein of adult birds using a 25-G needle. Birds return to the breeding colonies a couple of months prior to egg-laying (e.g., most birds return in early to mid-October at Bahía Esperanza/Hope Bay and Bird Island) (Burton, 1968; Carneiro et al., 2016; Ibañez, unpublished data). Blood samples were returned to the laboratory within 2-6 hours. Red blood cells were then isolated via centrifugation and removal of the supernatant, and stored frozen prior to laboratory analyses. Birds were sexed by the analysis of DNA extracted from blood samples at Bird Island, and by weight and tarsus lengths at Bahía Esperanza/Hope Bay and Signy Island (Fridolfsson and Ellegren, 1999; Phillips et al., 2002). The sexes of all birds assigned morphologically at Bahía Esperanza/Hope Bay were later confirmed by DNA analysis.

\subsection{Total mercury analysis}

The vast majority (>90\%) of total $\mathrm{Hg}$ (THg) in skua blood is MeHg (Renedo et al., 2018), and the estimated half-life of $\mathrm{Hg}$ in the blood of great skuas Stercorarius skua is 30-60 days (Bearhop et al., 2000b). Blood samples were freeze-dried and homogenised prior to analysis. THg concentrations of red blood cells (hereafter "blood THg") were measured using an Advanced Mercury Analyser spectrophotometer (Altec AMA 254) at the laboratory Littoral Environnement et Sociétés (LIENSs, France). For each sample, a minimum of two aliquots (range: $0.29-1.86 \mathrm{mg}$ dry weight $[\mathrm{dw}]$ ) were analysed, and the means and relative standard deviations between measurements were calculated (all samples relative standard deviation $<10 \%)$. THg concentrations are presented in $\mu \mathrm{g} \mathrm{g}^{-1} \mathrm{dw}$. Accuracy was tested using a certified reference material (dogfish liver DOLT-5, NRC, Canada; certified Hg concentration: $0.44 \pm$ $\left.0.18 \mu \mathrm{g} \mathrm{g}^{-1} \mathrm{dw}\right)$ every 10 samples. The measured values were $0.43 \pm 0.01 \mu \mathrm{g} \mathrm{g}^{-1} \mathrm{dw}(n=15)$, and hence the recovery was $97.8 \pm 1.7 \%$. Blanks were analysed at the beginning of each set of samples and the detection limit of the method was $0.005 \mu \mathrm{g} \mathrm{g}^{-1} \mathrm{dw}$. 


\subsection{Stable isotope analysis}

Stable isotope ratios were measured in the same blood samples as above. In great skuas, $\delta^{13} \mathrm{C}$ and $\delta^{15} \mathrm{~N}$ in blood have half-lives of 15.7 and 14.4 days, respectively (i.e., of similar magnitude to the integration period to $\mathrm{Hg}$, see above) (Bearhop et al., 2002). Stable isotope analyses were conducted at the Natural Environment Isotope Facility (NEIF) Stable Isotope Ecology Lab, SUERC. Stable isotope ratios of carbon and nitrogen were determined by a continuous-flow mass spectrometer (Delta Plus XP; Thermo Scientific, Bremen, Germany) coupled to an elemental analyser (vario PYRO cube; Elementar, Langenselbold, Germany). To correct for instrument drift, three internal laboratory standards were analysed for every 10 samples. Stable isotope ratios are reported as $\delta$-values and expressed as \%o according to the equation: $\delta \mathrm{X}=$ $\left[\left(\mathrm{R}_{\text {sample }} / \mathrm{R}_{\text {standard }}\right)-1\right] \times 10^{3}$, where $\mathrm{X}$ is ${ }^{13} \mathrm{C}$ or ${ }^{15} \mathrm{~N}, \mathrm{R}$ is the corresponding ratio ${ }^{13} \mathrm{C} /{ }^{12} \mathrm{C}$ or ${ }^{15} \mathrm{~N} /{ }^{14} \mathrm{~N}$, and $\mathrm{R}_{\text {standard }}$ is the ratio of international references Vienna PeeDee Belemnite for carbon and atmospheric $\mathrm{N}_{2}$ (AIR) for nitrogen. Measurement precision (standard deviation associated with replicate runs of USGS40) was $<0.2 \%$ for both $\delta^{13} \mathrm{C}$ and $\delta^{15} \mathrm{~N}$.

\subsection{Data analysis}

General linear models (GLMs; Gaussian distribution and identity link function) were used to assess variation in log-transformed blood THg concentrations. Predictor variables included sex, breeding colony (three-level factor), blood $\delta^{15} \mathrm{~N}$ and blood $\delta^{13} \mathrm{C}$ values. Blood $\delta^{15} \mathrm{~N}$ values were included as a predictor variable despite the baseline ${ }^{15} \mathrm{~N}$ enrichment with latitude in the Southern Ocean, as this is more pronounced at the Subtropical Front than south of the APF, where our study populations are located (Cherel and Hobson, 2007; Jaeger et al., 2010). Blood $\delta^{13} \mathrm{C}$ values of brown skuas differed significantly among breeding colonies (Kruskal-Wallis test, $\mathrm{H}=67.2, p<0.001$ ), and so separate models were parameterised with either the breeding colony or $\delta^{13} \mathrm{C}$ as an explanatory variable. Blood $\delta^{15} \mathrm{~N}$ and $\delta^{13} \mathrm{C}$ values were not highly correlated and were included in the same models (Spearman's correlation, $\mathrm{r}_{\mathrm{S}}=0.34, p<0.01$ ). Models included relevant two-way interactions among predictor variables and were ranked using the Akaike Information Criteria adjusted for small sample sizes $\left(\mathrm{AIC}_{\mathrm{C}}\right.$ ) and models within two $\mathrm{AIC}_{\mathrm{C}}$ units of the top model $\left(\leq 2 \mathrm{AIC}_{\mathrm{C}}\right)$ were considered equally plausible (Burnham and Anderson, 2002). Akaike weights $\left(\omega_{i}\right)$ were used to assess the weight of evidence in favour of a given model among the candidate set (Burnham and Anderson, 2002). All analyses were conducted using R version 3.4.4 (R Core Team, 2019). 


\section{Results}

Blood THg concentrations were measured in 82 individual brown skuas. Mean ( \pm SD) blood THg concentrations were $3.13 \pm 2.08 \mu \mathrm{g} \mathrm{g}^{-1} \mathrm{dw}$ (range: $0.49-8.67 \mu \mathrm{g} \mathrm{g}^{-1} \mathrm{dw}$ ) (Table 1). The most parsimonious GLM (i.e., $\Delta \mathrm{AIC}_{\mathrm{C}}=0.00$ ) explaining variation in log-transformed blood $\mathrm{THg}$ concentrations included breeding colony, which reflects an increase in mean blood $\mathrm{THg}$ concentrations from Bahía Esperanza/Hope Bay $\left(0.95 \pm 0.45 \mu \mathrm{g} \mathrm{g}^{-1} \mathrm{dw}\right.$, range: 0.49-2.33 $\mu \mathrm{g}$ $\left.\mathrm{g}^{-1} \mathrm{dw}, n=23\right)$ to Signy Island (3.42 $\pm 2.29 \mu \mathrm{g} \mathrm{g}^{-1} \mathrm{dw}$, range: $1.10-8.67 \mu \mathrm{g} \mathrm{g}^{-1} \mathrm{dw}, n=28$ ) and then Bird Island $\left(4.47 \pm 1.10 \mu \mathrm{g} \mathrm{g}^{-1} \mathrm{dw}\right.$, range: 3.02-7.46 $\mu \mathrm{g} \mathrm{g}^{-1} \mathrm{dw}, n=31$ ) (Table 1 and Fig. 2). The most parsimonious GLM also contained $\delta^{15} \mathrm{~N}$ values, sex and their interaction (Table 2 and Fig. 3A). This reflects a weak positive relationship between blood $\mathrm{THg}$ concentrations and blood $\delta^{15} \mathrm{~N}$ values, and that although the slopes differed between sexes, mean blood $\mathrm{THg}$ concentrations were higher in males than females in all populations (Table 1 and Fig. 3A). GLMs replacing the breeding colony variable with blood $\delta^{13} \mathrm{C}$ values produced similar results (Table 1), and indicated a strong positive relationship between blood $\mathrm{THg}$ concentrations and blood $\delta^{13} \mathrm{C}$ values (Fig. 3B).

\section{Discussion}

Antarctic marine ecosystems are often considered to be pristine environments, yet wildlife in the polar regions may still be exposed to high levels of environmental contaminants (Ibañez et al., 2020; Mills et al., 2020). This study provides a detailed evaluation of the underlying drivers of blood THg contamination of brown skuas from three breeding colonies located south of the APF in the Antarctic Zone of the Southern Ocean. Blood samples provide a non-lethal means of obtaining information about $\mathrm{Hg}$ contamination of seabirds, and measuring $\mathrm{THg}$ in skua blood samples provides information about contamination of prey and hence exposure to $\mathrm{MeHg}$ in food webs (Albert et al., 2019).

\subsection{Latitudinal differences: from the Antarctic Peninsula to South Georgia}

Our analysis demonstrates clear differences in $\mathrm{Hg}$ contamination of brown skuas among the three breeding colonies located at different latitudes south of the APF. Blood THg concentrations were lowest at the Antarctic Peninsula, intermediate at the South Orkney Islands and highest at South Georgia. Indeed, mean blood THg concentrations were 4.7x higher at Bird Island compared to Bahía Esperanza/Hope Bay. This pattern is corroborated by the strong positive correlation between $\mathrm{THg}$ and $\delta^{13} \mathrm{C}$ values (Fig. $3 \mathrm{~B}$ ), as $\delta^{13} \mathrm{C}$ increases from the Antarctic continent towards the subtropics in the Southern Ocean (Cherel and Hobson, 2007; 
Jaeger et al., 2010; Quillfeldt et al., 2005, 2010; Phillips et al. 2009; St John Glew et al., 2021). Hence, our study suggests geographic differences in the transfer of $\mathrm{Hg}$ to skuas in the southwest Atlantic sector of the Southern Ocean, and our first a priori prediction is supported. This result contrasts with other studies concluding that breeding latitude has a limited effect on $\mathrm{Hg}$ contamination of seabirds in waters south of the APF (Cherel et al., 2018; Carravieri et al., 2020). Nonetheless, a pattern of increasing $\mathrm{Hg}$ contamination of seabirds from Antarctic waters towards the sub-Antarctic and subtropics is commonly observed in the Southern Hemisphere (Carravieri et al., 2014b, 2016, 2017, 2020; Cherel et al., 2018; Mills et al., 2020; Renedo et al., 2020). For instance, blood THg concentrations of skua chicks in the southern Indian Ocean increase from breeding sites in the Antarctic to those in the sub-Antarctic and subtropics, with skuas at Amsterdam Island showing the highest recorded concentrations for seabird chicks globally (3.98 $\pm 0.77 \mu \mathrm{g} \mathrm{g}^{-1} \mathrm{dw}$ ) (Carravieri et al., 2017; Table 3). The majority of MeHg accumulated by seabirds has a mesopelagic origin, and it has been suggested that more efficient methylation of $\mathrm{Hg}$ at depth at lower compared to higher latitudes (i.e., subtropical compared to Antarctic waters), combined with higher vertical mixing, could deliver newly formed $\mathrm{MeHg}$ to the surface and therefore determine the regional differences in the bioavailability to seabirds (Renedo et al., 2020). To our knowledge, birds from Bahía Esperanza/Hope Bay show the lowest mean blood $\mathrm{THg}$ concentrations among adults of all large skua species for which data are available (Table 3); whereas blood THg concentrations at Bird Island were only lower than adults from Kerguelen, and great skuas from St Kilda (Table 3).

Differences in $\mathrm{Hg}$ contamination among the three breeding colonies may also be exacerbated by dietary differences. Blood $\delta^{13} \mathrm{C}$ values suggest that not all brown skuas from our study populations feed exclusively on Antarctic prey during the incubation and pre-laying periods (i.e., the timeframe reflected by blood $\delta^{13} \mathrm{C}$ values), and feed to some degree on prey from warmer waters north of the APF (Fig. 3B). At Bird Island, brown skuas mainly undertake coastal foraging trips during incubation and feed on the placentae from Antarctic fur seals Arctocephalus gazella, supplemented by carrion, particularly male seals killed during territorial conflicts (Phillips et al., 2004; Anderson et al., 2009b; Carneiro et al., 2014). Many of the female fur seals would have spent the winter foraging north of the APF, and potentially over the Patagonian Shelf (Staniland et al., 2012). Conversely, pellet analyses indicate that penguins are the dominant prey consumed at the higher latitude colonies (Signy Island and Bahía Esperanza/Hope Bay) (Burton, 1968; Graña Grilli and Montalti, 2015; Borghello et al., 2019; Ibañez et al., unpublished data), which forage in Antarctic waters (Lynnes et al., 2002). Indeed, the brown skuas at Bahía Esperanza/Hope Bay breed in close proximity to a large Adélie 
penguin Pygoscelis adeliae colony (approximately 100,000 breeding pairs), and two smaller gentoo penguin P. papua colonies (Santos et al., 2018; Borghello et al., 2019). Another contributing factor is that birds may undertake a pre-laying exodus after returning to the colony. A considerable proportion of brown skuas from Bird Island perform a pre-laying exodus north to sub-Antarctic and mixed sub-Antarctic-subtropical waters where the bioavailability of $\mathrm{Hg}$ is relatively high (Phillips et al., 2007; Carneiro et al., 2016a). Unfortunately, the pre-laying exodus is not well described at other colonies, including at the higher latitude breeding colonies studied here. Prey ingested around the colony during breeding will therefore represent the primary influence on blood THg in skuas; however, there may be a weak carry-over effect of $\mathrm{Hg}$ exposure during winter, and hence differing migration strategies may also have contributed to the patterns observed here.

\subsection{Relationships with blood $\delta^{15} N$ values}

The most parsimonious GLMs explaining blood THg concentrations included blood $\delta^{15} \mathrm{~N}$ values as a predictor variable, which provide a proxy for trophic position, and supports our second a priori prediction. Although the slopes differed between sexes, the weak positive correlation between blood $\mathrm{THg}$ and $\delta^{15} \mathrm{~N}$ values is likely to reflect, at least in part, the biomagnification of $\mathrm{MeHg}$ within marine food webs, such that individuals foraging at higher trophic levels were exposed to greater levels of $\mathrm{Hg}$. However, the positive relationships between blood THg and $\delta^{13} \mathrm{C}$ values were stronger than with $\delta^{15} \mathrm{~N}$ values (Fig. 3A and Fig. 3B). Biomagnification of $\mathrm{Hg}$ has been demonstrated in the Scotia Sea ecosystem, from particulate organic matter through to higher trophic levels (Anderson et al., 2009a; Seco et al., 2021). Indeed, mean blood THg concentrations of several large seabird species in our study region are higher than those of brown skuas in this study; however, it is notable that those of southern giant petrels Macronectes giganteus $\left(2.74 \pm 1.05 \mu \mathrm{g} \mathrm{g}^{-1} \mathrm{dw}\right.$, range: $\left.1.52-4.74 \mu \mathrm{g} \mathrm{g}^{-1} \mathrm{dw}\right)$, and northern giant petrels $M$. halli $\left(3.93 \pm 1.37 \mu \mathrm{g} \mathrm{g}^{-1} \mathrm{dw}\right.$, range: $\left.2.18-6.38 \mu \mathrm{g} \mathrm{g}^{-1} \mathrm{dw}\right)$ from Bird Island in 2001/02 were lower than in brown skuas from Bird Island in 2014/15 (Anderson et al., 2009a; this study). The relationship between $\delta^{15} \mathrm{~N}$ and $\mathrm{Hg}$ contamination is often apparent when comparing values among different species within seabird communities (e.g., Blévin et al., 2013; Anderson et al., 2009a), but is observed less frequently within a single species, and was apparent across our study populations despite relatively little variation in $\delta^{15} \mathrm{~N}$ values (range: 10.2 to $12.8 \%$ ). Alternatively, because there is a baseline ${ }^{15} \mathrm{~N}$ enrichment from the Antarctic towards the subtropics in the Southern Ocean (Cherel and Hobson, 2007; Jaeger et al., 2010), the relationship between $\mathrm{Hg}$ and $\delta^{15} \mathrm{~N}$ may simply reflect the increasing 
contamination with latitude (i.e., trophic variation may be obscured by spatial variation). However, changes in baseline $\delta^{15} \mathrm{~N}$ are less pronounced south of the APF (Cherel and Hobson, 2007; Jaeger et al., 2010). Moreover, differences in mean blood $\delta^{15} \mathrm{~N}$ values among populations were small (means at Bird Island are $\sim 0.2$ \% higher than at Bahía Esperanza/Hope Bay; Table 1), and mean $\delta^{15} \mathrm{~N}$ values were slightly lower at Signy Island than at Bahía Esperanza/Hope Bay (Table 1).

\subsection{Sex differences in $\mathrm{Hg}$ contamination}

Sex was also included as a predictor variable in the most parsimonious GLM, and blood THg was lower in females than males at each breeding colony (Table 1). Hence, our third a priori prediction is supported. As the blood samples were taken in mid to late incubation, two nonmutually exclusive hypotheses may explain the sex differences. First, egg production offers a route by which females are able to eliminate $\mathrm{Hg}$ (Bond and Diamond, 2008; Robinson et al., 2012; Ackerman et al., 2020), and Hg in eggs is thought to reflect dietary intake by females in the period before laying (Lewis et al., 1993; Monteiro and Furness, 1995). Second, our data show slight sex differences in blood $\delta^{15} \mathrm{~N}$ and $\delta^{13} \mathrm{C}$ values for all three populations (Table 1); hence, there may also be trophic differences between sexes. At Bird Island at least, females are more likely than males to undertake a pre-laying exodus (Phillips et al., 2007; Carneiro et al., 2016a). However, during late incubation and early chick-rearing at Bird Island, the sexes show similar territorial attendance, foraging time and habitat use, and a previous stable isotope study at South Georgia found no evidence for sex-specific foraging preferences during the breeding period (Anderson et al., 2009b; Carneiro et al., 2014). This is despite pronounced reverse sexual size dimorphism in this species (Catry et al., 1999; Phillips et al., 2002).

\subsection{Could Hg contamination have fitness implications?}

$\mathrm{Hg}$ is a neurotoxin and endocrine disruptor (Tan et al., 2009), and contamination may impact various aspects of development, physiology and breeding behaviour in seabirds (Burger and Gochfeld, 1997; Evers et al., 2008; Tartu et al., 2013; Goutte et al., 2015). Hg contamination has also been associated with reduced breeding success (Goutte et al., 2014; Ackerman et al., 2016; Mills et al., 2020). The mean blood THg (dw) concentrations reported here are equivalent to $0.94 \mu \mathrm{g} \mathrm{g}^{-1}$ wet weight (ww), $0.72 \mu \mathrm{g} \mathrm{g}^{-1} \mathrm{ww}$ and $0.20 \mu \mathrm{g} \mathrm{g}^{-1} \mathrm{ww}$ at Bird Island, Signy Island and Bahía Esperanza/Hope Bay, respectively (assuming a 79\% moisture content) (Eagles-

Smith et al., 2008; Ackerman et al., 2016). These values suggest a low risk of MeHg toxicity (Ackerman et al., 2016). Indeed, mean blood THg concentrations in our study were far lower 
than those of brown skuas at Kerguelen; however, blood THg concentrations at Bird Island and Signy Island exceeded those of south polar skuas Stercorarius maccormicki at Adélie Land (Goutte et al., 2014; Table 3). Goutte et al. (2014) found short-term associations between Hg contamination and breeding success in both skua species, yet long-term reproductive impacts were more severe in south polar skuas than brown skuas, despite their lower blood $\mathrm{THg}$ concentrations. Selenium (Se) offers a well-known protective effect against $\mathrm{Hg}$ toxicity when in molar excess (i.e., when $\mathrm{Se}: \mathrm{Hg}>1$ ), and blood Se:Hg molar ratios of south polar skuas were three times lower than the brown skuas (Carravieri et al., 2017; Manceau et al., 2021). Hence, although it currently appears unlikely that there are fitness consequences of $\mathrm{Hg}$ contamination for brown skuas in our study region (though we did not test this directly), the role of Se requires evaluation. Populations of brown skuas at Signy Island and Bird Island increased rapidly from the late-1950s to early-1980s (by $3.3 \%$ and $3.6 \%$ pa, respectively), but then rates slowed until the 2010s (0.4\% pa) and 2000s (0.9\% pa), respectively (Phillips et al., 2004; Carneiro et al., 2016b). Rather than a consequence of $\mathrm{Hg}$ contamination, the slower population growth rates seem more likely to be related to changes in prey availability and increased density-dependent competition (Phillips et al., 2004; Carneiro et al., 2016b).

\section{Conclusion}

Our study provides important baseline data on $\mathrm{Hg}$ contamination of brown skuas in the Southern Ocean, and analyses the underlying drivers of variation in contamination. Given the relatively high levels of $\mathrm{Hg}$ contamination of brown skuas at Bird Island, which in the early 2000s was likely the most densely-populated colony in the world (132 nesting pairs per $\mathrm{km}^{2}$ of suitable habitat) (Phillips et al., 2004), further monitoring is required, particularly as there is some evidence for increasing $\mathrm{Hg}$ contamination of other seabirds at South Georgia (Mills et al., 2020). Moreover, $\mathrm{MeHg}$ concentrations peak in low-oxygen subsurface waters, and in a warming world, oxygen minimum zones are expected to increase, hence potentially enhancing methylation of $\mathrm{Hg}$ and its bioavailability to marine predators (Blum et al., 2013). Further work should also examine the potential protective effects of Se on $\mathrm{Hg}$ toxicity in brown skuas, and the risks posed by other contaminants to these skua populations, especially given the incidence of plastic ingestion by this species at the Antarctic Peninsula and the potential role of plastics in contaminant transmission (Lavers and Bond, 2016; Ibañez et al., 2020). 


\section{Declaration of competing interest}

The authors declare that they have no known competing financial interests or personal relationships that could have appeared to influence the work reported in this paper.

\section{Acknowledgements}

William Mills is supported by a NERC GW4+ Doctoral Training Partnership studentship from the Natural Environment Research Council (NERC; grant no. NE/L002434/1). The Institut Universitaire de France (IUF) is acknowledged for its support to Paco Bustamante as a Senior Member. Stable isotope analyses were funded by the Natural Environment Isotope Facility (grant no. 2325.0920). The authors are grateful to Maud Brault-Favrou for her assistance with $\mathrm{Hg}$ analyses. Thanks are also due to the CPER (Contrat de Projet Etat-Région) and the FEDER (Fonds Européen de Développement Régional) for funding the AMA of LIENSs laboratory. The authors are also grateful to the Dirección Nacional del Antártico (DNA) and Instituto Antártico Argentino (IAA) for the support of the field-work activities and logistics in the Antarctic. Thanks to CONICET and Agencia Nacional de Promoción Cientifica y Tecnológica (ANPCyT) for the financial support. Comments from two anonymous reviewers greatly improved the manuscript. This work represents a contribution to the Ecosystems component of the British Antarctic Survey Polar Science for Planet Earth Programme, funded by the Natural Environment Research Council.

\section{CRediT authorship statement}

WFM: Conceptualization, Methodology, Investigation, Formal Analysis, Visualization, Writing - Original Draft. AEI: Conceptualization, Methodology, Investigation, Resources, Writing - Review \& Editing. PB: Investigation, Writing - Review \& Editing. APBC: Resources, Investigation, Writing - Review \& Editing. SB: Supervision, Writing - Review \& Editing. YC: Supervision, Writing - Review \& Editing. RM-J: Supervision, Investigation, Writing - Review \& Editing. RARM: Investigation, Writing - Review \& Editing. DM: Supervision, Writing Review \& Editing. SCV: Supervision, Writing - Review \& Editing. RAP: Conceptualization, Methodology, Investigation, Resources, Supervision, Writing - Review \& Editing. 


\section{References}

Ackerman, J.T., Eagles-Smith, C.A., Herzog, M.P., Hartman, C.A., Peterson, S.H., Evers, D.C., Jackson, A.K., Elliott, J.E., Vander Pol, S.S. and Bryan, C.E. 2016. Avian mercury exposure and toxicological risk across western North America: a synthesis. Sci. Total Environ. 568, 749-769.

Ackerman, J.T., Herzog, M.P., Evers, D.C., Cristol, D.A., Kenow, K.P., Heinz, G.H., Lavoie, R.A., Brasso, R.L., Mallory, M.L., Provencher, J.F., Braune, B.M., Matz, A., Schumtz, J.A., Eagles-Smith, C.A., Savoy, L.J., Meyer, M.W. and Hartman, C.A. 2020. Synthesis of maternal transfer of mercury in birds: implications for altered toxicity risk. Environ. Sci. Technol. 54, 2878-2891.

Albert, C., Renedo, M., Bustamante, P. and Fort, J. 2019. Using blood and feathers to investigate large-scale Hg contamination in Arctic seabirds: a review. Environ. Res. 177, 108588.

Anderson, O.R.J., Phillips, R.A., McDonald, R.A., Shore, R.F., McGill, R.A.R. and Bearhop, S. 2009a. Influence of trophic position and foraging range on mercury levels within a seabird community. Mar. Ecol. Prog. Ser. 375, 277-288.

Anderson, O.R.J., Phillips, R.A., Shore, R.F., McGill, R.A.R., McDonald, R.A. and Bearhop, S. 2009b. Diet, individual specialisation and breeding of brown skuas (Catharacta antarctica lonnbergi): an investigation using stable isotopes. Polar Biol. 32, 27-33.

Bargagli, R., Monaci, F., Sanchez-Hernandez, J.C. and Cateni, D. 1998. Biomagnification of mercury in an Antarctic marine coastal food web. Mar. Ecol. Prog. Ser. 169, 65-76.

Bearhop, S., Phillips, R.A., Thompson, D.R., Waldron, S. and Furness, R.W. 2000a. Variability in mercury concentrations of great skuas Catharacta skua: the influence of colony, diet and trophic status inferred from stable isotope signatures. Mar. Ecol. Prog. Ser. 195, 261268.

Bearhop, S., Ruxton, G.D. and Furness, R.W. 2000b. Dynamics of mercury in blood and feathers of great skuas. Environ. Toxicol. Chem. 19, 1638-1643.

Bearhop, S., Waldron, S., Thompson, D. and Furness, R. 2000c. Bioamplification of mercury in great skua Catharacta skua chicks: the influence of trophic status as determined by stable isotope signatures of blood and feathers. Mar. Pollut. Bull. 40: 181-185.

Bearhop, S., Waldron, S., Votier, S.C. and Furness, R.W. 2002. Factors that influence assimilation rates and fractionation of nitrogen and carbon stable isotopes in avian blood and feathers. Physiol. Biochem. Zool. 75, 451-458. 
Becker, P.H., Goutner, V., Ryan, P.G. and González-Solís, J. 2016. Feather mercury concentrations in Southern Ocean seabirds: variation by species, site and time. Environ. Pollut. 216, 253-263.

Blévin, P., Carravieri, A., Jaeger, A., Chastel, O., Bustamante, P. and Cherel, Y. 2013. Wide range of contamination in chicks of Southern Ocean seabirds. PLoS ONE 8, e54508.

Blum, J.B., Popp, B.N., Drazen, J.C., Choy, C.A. and Johnson, M.W. 2013. Methyl-mercury production below the mixed layer in the North Pacific Ocean. Nat. Geosci. 6, 879-884.

Bond, A.L. 2010 Relationships between stable isotopes and metal contaminants in feathers are spurious and biologically uninformative. Environ. Pollut. 158, 1182-1184.

Bond, A.L. and Diamond, A.W. 2008. Total and methyl mercury concentrations in seabird feathers and eggs. Arch. Environ. Contam. Toxicol. 56, 286-291.

Borghello, P., Torres, D.S., Montalti, D. and Ibañez, A.E. 2019. Diet of the brown skua (Stercorarius antarcticus lonnbergi) at Hope Bay, Antarctic Peninsula: differences between breeders and non-breeders. Polar Biol. 42, 385-394.

Burger, J. and Gochfeld, M. 1997. Risk, mercury levels, and birds: Relating adverse laboratory effects to field biomonitoring. Environ. Res. 75, 160-172.

Burnham, K.P. and Anderson, D.R. 2002. Model Selection and Inference: A Practical Information-theoretic Approach. Springer, New York, NY.

Burton, R.W. 1968. Breeding biology of the brown skua, Catharacta skua lonnbergi (Mathews), at Signy Island, South Orkney Island. Br. Antarct. Surv. Bull. 15, 9-28.

Carneiro, A.P.B., Manica, A. and Phillips, R.A. 2014. Foraging behaviour and habitat use by brown skuas Stercorarius lonnbergi breeding at South Georgia. Mar. Biol. 161, 17551764.

Carneiro, A.P.B., Manica, A., Clay, T.A., Silk, J.R.D., King, M. and Phillips, R.A. 2016a. Consistency in migration strategies and habitat preferences of brown skuas over two winters, a decade apart. Mar. Ecol. Prog. Ser. 553:267-281.

Carneiro, A.P.B., Manica, A. and Phillips, R.A. 2016b. Long-term changes in population size, distribution and productivity of skuas (Stercorarius spp.) at Signy Island, South Orkney Islands. Polar Biol. 39, 617-625.

Carravieri, A., Cherel, Y., Blévin, P., Brault-Favrou, M., Chastel, O. and Bustamante, P. 2014a. Mercury exposure in a large subantarctic avian community. Environ. Pollut. 190, 51-57. Carravieri, A., Bustamante, P., Tartu, S., Meillere, A., Labadie, P., Budzinski, H., Peluhet, L., Barbraud, C., Weimerskirch, H., Chastel, O. and Cherel, Y. 2014b. Wandering 
albatrosses document latitudinal variations in the transfer of persistent organic pollutants and mercury to Southern Ocean predators. Environ. Sci. Technol. 48, 14746-14755.

Carravieri, A., Cherel, Y., Jaeger, A., Churlaud, C. and Bustamante, P. 2016. Penguins as bioindicators of mercury contamination in the southern Indian Ocean: geographical and temporal trends. Environ. Pollut. 213, 195-205.

Carravieri, A., Cherel, Y., Brault-Favrou, M., Churlaud, C., Peluhet, L., Labadie, P., Budzinski, H., Chastel, O. and Bustamante, P. 2017. From Antarctica to the subtropics: contrasted geographical concentrations of selenium, mercury, and persistent organic pollutants in skua chicks (Catharacta spp.). Environ. Pollut. 228, 464-473.

Carravieri, A., Bustamante, P., Labadie, P., Budzinski, H., Chastel, O. and Cherel, Y. 2020.

Trace elements and persistent organic pollutants in chicks of 13 seabird species from Antarctica to the subtropics. Environ. Int. 134, 105225.

Catry, P., Phillips, R.A. and Furness, R.W. 1999. Evolution of reversed sexual size dimorphism in skuas and jaegers. Auk 116, 158-168.

Cherel, Y., Hobson, K.A. and Weimerskirch, H. 2000. Using stable-isotope analysis of feathers to distinguish moulting and breeding origins of seabirds. Oecologia 122, 155-162.

Cherel, Y. and Hobson, K.A. 2007. Geographical variation in carbon stable isotope signatures of marine predators: a tool to investigate their foraging areas in the Southern Ocean. Mar. Ecol. Prog. Ser. 329, 281-287.

Cherel, Y., Barbraud, C., Lahournat, M., Jaeger, A., Jaquemet, S., Wanless, R.M., Phillips, R.A., Thompson, D.R. and Bustamante, P. 2018. Accumulate or eliminate? Seasonal mercury dynamics in albatrosses, the most contaminated family of birds. Environ. Pollut. 241, 124-135.

Driscoll, C.T., Mason, R.P., Chan, H.M., Jacob, D.J. and Pirrone, N. 2013. Mercury as a global pollutant: sources, pathways, and effects. Environ. Sci. Technol. 47, 4967-4983.

Eagles-Smith, C.A., Ackerman, J.T., Adelsbach, T.L., Takekawa, J.Y., Miles, A.K., Keister, R.A. 2008. Mercury correlations among six tissues for four waterbird species breeding in San Francisco Bay, California, USA. Environ. Toxicol. Chem. 27, 2136-2153.

Eagles-Smith, C.A., Silbergeld, E.K., Basu, N., Bustamante, P., Diaz-Barriga, F., Hopkins, W.A., Kidd, K.A. and Nyland, J.F. 2018. Modulators of mercury risk to wildlife and humans in the context of rapid global change. Ambio 47, 170-197.

Elliott, K.H., Braune, B.M. and Elliott, J.E. 2021. Beyond bulk $\delta^{15} \mathrm{~N}$ : combining a suite of stable isotopic measures improves the resolution of the food webs mediating contaminant signals across space, time and communities. Environ. Int. 148, 106370. 
Evers, D.C., Savoy, L.J., DeSorbo, C.R., Yates, D.E., Hanson, W., Taylor, K.M., Siegel, L.S., Cooley, J.H. Jr., Bank, M.S., Major, A., Munney, K., Mower, B.F., Vogel, H.S., Schoch, N., Pokras, M., Goodale, M.W. and Fair, J. 2008. Adverse effects from environmental mercury loads on breeding common loons. Ecotoxicology 17, 69-81.

Fitzgerald, W.F., Engstrom, D.R., Mason, R.P. and Nater, E.A. 1998. The case for atmospheric mercury contamination in remote areas. Environ. Sci. Technol. 32, 1-7.

Fridolfsson, A.K. and Ellegren, H. 1999. A simple and universal method for molecular sexing of non-ratite birds. J. Avian Biol. 30, 116-121.

Furness, R.W. 1987. The skuas. T. and A. D. Poyser, Calton, United Kingdom.

Goutte, A., Bustamante, P., Barbraud, C., Delord, K., Weimerskirch, H. and Chastel, O. 2014. Demographic responses to mercury exposure in two closely-related Antarctic top predators. Ecology 95, 1075-1086.

Goutte, A., Barbraud, C., Herzke, D., Bustamante, P., Angelier, F., Tartu, S., Clément-Chastel, C., Moe, B., Bech, C., Gabrielsen, G.W., Bustnes, J.O. and Chastel, O. 2015. Survival rate and breeding outputs in a high Arctic seabird exposed to legacy persistent organic pollutants and mercury. Environ. Pollut. 200, 1-9.

Graña Grilli, M.G. and Montalti, D. 2015. Variation in diet composition during the breeding cycle of an Antarctic seabird in relation to its breeding chronology and that of its main food resource. Polar Biol. 38, 643-649.

Hobson K.A. and Clark R.G. 1992. Assessing avian diets using stable isotopes I: turnover of ${ }^{13} \mathrm{C}$ in tissues. Condor $94,181-188$.

Ibañez, A.E., Morales, L.M., Torres, D.S., Borghello, P., Haidr, N.S. and Montalti, D. 2020. Plastic ingestion risk is related to the anthropogenic activity and breeding stage in an Antarctic top predator seabird species. Mar. Pollut. Bull. 157, 111351.

Inger, R. and Bearhop, S. 2008. Applications of stable isotope analyses to avian ecology. Ibis $150,447-461$.

Jaeger, A., Lecomte, V.J., Weimerskirch, H., Richard, P. and Cherel, Y. 2010. Seabird satellite tracking validates the use of latitudinal isoscapes to depict predators' foraging areas in the Southern Ocean. Rapid Commun. Mass Spectrom. 24, 3456-3460.

Lavers, J.L. and Bond, A.L. 2016. Ingested plastic as a route for trace metals in Laysan Albatross (Phoebastria immutabilis) and Bonin Petrel (Pterodroma hypoleuca) from Midway Atoll. Mar. Pollut. Bull. 110, 493-500. 
Lewis, S.A., Becker, P.H. and Furness, R.W. 1993. Mercury levels in eggs, tissues, and feathers of herring gulls Larus argentatus from the German Wadden Sea Coast. Environ. Pollut. 80, 293-299.

Lynnes, A.S., Reid, K., Croxall, J.P. and Trathan, P.N. 2002. Conflict or co-existence? Foraging distribution and competition for prey between Adélie and chinstrap penguins. Mar. Biol. 141, 1165-1174

Manceau, A., Gaillot, A-C., Glatzel, P., Cherel, Y. and Bustamante, P. 2021. In vivo formation of $\mathrm{HgSe}$ nanoparticles and $\mathrm{Hg}$-tetraselenolate complex from methylmercury in seabirds - implications for the Hg-Se antagonism. Environ. Sci. Technol. 55, 1515-1526.

Mills, W.F., Bustamante, P., McGill, R.A.R., Anderson, O.R.J., Bearhop, S., Cherel, Y., Votier, S.C. and Phillips, R.A. 2020. Mercury exposure in an endangered seabird: longterm changes and relationships with trophic ecology and breeding success. Proc. R. Soc. B 287, 20202683.

Monteiro, L.R. and Furness, R.W. 1995. Seabirds as monitors of mercury in the marine environment. Water Air Soil Pollut. 80, 851-870.

Monteiro, L.R., Costa, V., Furness, R.W. and Santos, R.S. 1996. Mercury concentrations in prey fish indicate enhanced bioaccumulation in mesopelagic environments. Mar. Ecol. Prog. Ser. 141, 21-25.

Peterson, B.J. and Fry, B. 1987. Stable isotopes in ecosystem studies. Annu. Rev. Ecol. Syst. $18,293-320$.

Phillips, R.A., Dawson, D.A. and Ross, D.J. 2002. Mating patterns and reversed size dimorphism in Southern skuas (Stercorarius skualonnbergi). Auk 119, 858-863.

Phillips, R.A., Phalan, B. and Forster, I.P. 2004. Diet and long-term changes in population size and productivity of brown skuas Catharacta antarctica lonnbergi at Bird Island, South Georgia. Polar Biol. 27, 555-561.

Phillips, R.A., Catry, P., Silk, J.R.D., Bearhop, S., McGill, R.A.R., Afanasyev, V. and Strange, I.J. 2007. Movements, winter distribution and activity patterns of Falkland and brown skuas: insights from loggers and isotopes. Mar. Ecol. Prog. Ser. 345: 281-291.

Phillips, R.A., Bearhop, S., McGill, R.A.R. and Dawson, D.A. 2009. Stable isotopes reveal individual variation in migration strategies and habitat preferences in a suite of seabirds during the nonbreeding period. Oecologia 160: 795-806.

Phillips, R.A., McGill, R.A.R., Dawson, D.A. and Bearhop, S. 2011. Sexual segregation in distribution, diet and trophic level of seabirds: insights from stable isotope analysis. Mar. Biol. 158: 2199-2208. 
Polito, M.J., Brasso, R.L., Trivelpiece, W.Z., Karnovsky, N., Patterson, W.P. and Emslie, S.D. 2016. Differing foraging strategies influence mercury $(\mathrm{Hg})$ exposure in an Antarctic penguin community. Environ. Pollut. 218, 196-206.

Quillfeldt, P., McGill, R.A.R. and Furness, R.W. 2005. Diet and foraging areas of Southern Ocean seabirds and their prey inferred from stable isotopes: review and case study of Wilson's storm-petrel. Mar. Ecol. Prog. Ser. 295, 295-304.

Quillfeldt, P., Masello, J.F., McGill, R.A.R., Adams, M. and Furness, R.W. 2010. Moving polewards in winter: a recent change in the migratory strategy of a pelagic seabird? Front. Zool. 7, 15.

R Core Team (2019) R: A Language and Environment for Statistical Computing. Vienna, Austria. https://www.R-project.org/

Reinhardt, K., Hahn, S., Peter, H-U. and Wemhoff, H. 2000. A review of the diets of Southern Hemisphere skuas. Mar. Ornithol. 28, 7-19.

Renedo, M., Amouroux, D., Duval, B., Carravieri, A., Tessier, E., Barre, J., Bérail, S., Pedrero, Z., Cherel, Y. and Bustamante, P. 2018. Seabird tissues as efficient biomonitoring tools for $\mathrm{Hg}$ isotopic investigations: Implications of using blood and feathers from chicks and adults. Environ. Sci. Technol. 52, 4227-4234.

Renedo, M., Bustamante, P., Cherel, Y., Pedrero, Z., Tessier, E. and Amouroux, D. 2020. A "seabird-eye" on mercury stable isotopes and cycling in the Southern Ocean. Sci. Total Environ. 742, 140499.

Robinson, S.A., Lajeunesse, M.J. and Forbes, M.R. 2012. Sex differences in mercury contamination of birds: testing multiple hypotheses with meta-analysis. Environ. Sci. Technol. 46, 7094-7101.

Santos, M.M., Hinke, J.T., Coria, N.R., Fusaro, B., Silvestro, A. and Juáres, M.A. 2018. Abundance estimation of Adélie penguins at the Esperanza/Hope Bay mega colony. Polar Biol. 41, 2337-2342.

Seco, J., Aparício, S., Brierley, A.S., Bustamante, P., Ceia, F.R., Coelho, J.P., Philips, R.A., Saunders, R.A., Fielding, S., Gregory, S. and Matias, R., 2021. Mercury biomagnification in a Southern Ocean food web. Environ. Pollut. 275, 116620.

St John Glew, K., Espinasse, B., Hunt, B.P., Pakhomov, E.A., Bury, S.J., Pinkerton, M., Nodder, S.D., Gutiérrez Rodríguez, A., Safi, K., Brown, J.C. and Graham, L., 2021. Isoscape models of the Southern Ocean: predicting spatial and temporal variability in carbon and nitrogen isotope compositions of particulate organic matter. Global Biogeochem. Cycles 35, e2020GB006901. 
Staniland, I.J., Robinson, S.L., Silk, J.R.D., Warren, N. and Trathan, P.N. 2012. Winter distribution and haul-out behaviour of female Antarctic fur seals from South Georgia. Mar. Biol. 159, 291-301.

Tan, S.W., Meiller, J.C., Mahaffey, K.R. 2009. The endocrine effects of mercury in humans and wildlife. Crit. Rev. Toxicol. 39, 228-269.

Tartu, S., Goutte, A., Bustamante, P., Angelier, F., Moe, B., Clément-Chastel, C., Bech, C., Gabrielsen, G.W., Bustnes, J.O., Chastel, O., 2013. To breed or not to breed: endocrine response to mercury contamination by an Arctic seabird. Biol. Lett. 9, 20130317.

UN Environment. 2019. Global Mercury Assessment 2018. UN Environment Programme, Chemicals and Health Branch, Geneva, Switzerland. 
Table 1. Total mercury ( $\mathrm{THg}$ ) concentrations $\left(\mu \mathrm{g} \mathrm{g}^{-1} \mathrm{dw}\right.$ ) in red blood cells sampled from adult brown skuas Stercorarius antarcticus lonnbergi

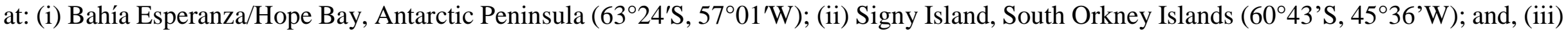
Bird Island, South Georgia $\left(54^{\circ} 00^{\prime} \mathrm{S}, 38^{\circ} 03^{\prime} \mathrm{W}\right)$. Values are means \pm SDs.

\begin{tabular}{lcclccc}
\hline Breeding population & Year & $n$ & Sex & $\mathrm{THg}\left(\mu \mathrm{g} \mathrm{g}{ }^{-1} \mathrm{dw}\right)$ & $\delta^{15} \mathrm{~N}(\%)$ & $\delta^{13} \mathrm{C}(\%)$ \\
\hline Bahía Esperanza/Hope Bay, Antarctic Peninsula & 2019 & 12 & Male & $1.02 \pm 0.50$ & $11.61 \pm 0.49$ & $-23.26 \pm 0.26$ \\
& & 11 & Female & $0.87 \pm 0.40$ & $11.25 \pm 0.53$ & $-23.06 \pm 0.41$ \\
Signy Island, South Orkney Islands & & 23 & Both & $0.95 \pm 0.45$ & $11.44 \pm 0.53$ & $-23.17 \pm 0.35$ \\
& 2014 & 15 & Male & $3.92 \pm 2.30$ & $11.44 \pm 0.48$ & $-22.29 \pm 0.52$ \\
& & 13 & Female & $2.85 \pm 2.23$ & $11.24 \pm 0.65$ & $-22.10 \pm 0.39$ \\
Bird Island, South Georgia & & 28 & Both & $3.42 \pm 2.29$ & $11.35 \pm 0.56$ & $-22.20 \pm 0.47$ \\
& 2015 & 14 & Male & $4.86 \pm 1.12$ & $11.81 \pm 0.51$ & $-20.17 \pm 0.22$ \\
& & 17 & Female & $4.15 \pm 1.00$ & $11.50 \pm 0.61$ & $-20.31 \pm 0.29$ \\
& & 31 & Both & $4.47 \pm 1.10$ & $11.64 \pm 0.58$ & $-20.24 \pm 0.26$ \\
\hline
\end{tabular}


Table 2. Model selection for factors explaining variation in log-transformed total mercury ( $\mathrm{THg}$ ) concentrations ( $\left.\mu \mathrm{g} \mathrm{g}^{-1} \mathrm{dw}\right)$ of red blood cells from adult brown skuas Stercorarius antarcticus lonnbergi. The top 4 models are shown, and all are GLMs (Gaussian distribution and identity link function). $\mathrm{k}$ is the number of parameters; $\Delta \mathrm{AIC}_{\mathrm{C}}$ is the change in the Akaike information criterion corrected for small sample sizes (AIC $\mathrm{C}$ ) from the best-supported model; $\omega_{\mathrm{i}}$ is the Akaike weight; Exp. Dev. is the percentage explained deviance of the top model.

\begin{tabular}{|c|c|c|c|c|}
\hline Models & $\mathrm{k}$ & $\Delta \mathrm{AIC}_{\mathrm{C}}$ & $\omega_{\mathrm{i}}^{\mathrm{a}}$ & Exp. Dev. $(\%)$ \\
\hline \multicolumn{5}{|c|}{ Maximal model: $\mathrm{THg} \sim$ Sex + Site $+\delta^{15} \mathrm{~N}+$ Sex $: \delta^{15} \mathrm{~N}+$ Site:Sex + Site $: \delta^{15} \mathrm{~N}$} \\
\hline $\mathrm{THg} \sim \operatorname{Sex}+$ Site $+\delta^{15} \mathrm{~N}+$ Sex $: \delta^{15} \mathrm{~N}$ & 7 & 0.00 & 0.57 & 79.1 \\
\hline $\mathrm{THg} \sim \operatorname{Sex}+$ Site $+\delta^{15} \mathrm{~N}+$ Sex $: \delta^{15} N+$ Site:Sex & 9 & 2.32 & 0.18 & \\
\hline $\mathrm{THg} \sim$ Sex + Site $+\delta^{15} \mathrm{~N}+$ Sex $: \delta^{15} \mathrm{~N}+$ Site $: \delta^{15} \mathrm{~N}$ & 9 & 2.83 & 0.14 & \\
\hline THg $\sim$ Sex + Site $+\delta^{15} N+$ Sex $: \delta^{15} N+$ Site:Sex + Site $: \delta^{15} N$ & 13 & 5.44 & 0.04 & \\
\hline \multicolumn{5}{|c|}{ Maximal model ${ }^{\mathrm{b}}: \mathrm{THg} \sim \operatorname{Sex}+\delta^{13} \mathrm{C}+\delta^{15} \mathrm{~N}+\operatorname{Sex}: \delta^{13} \mathrm{C}+\operatorname{Sex}: \delta^{15} \mathrm{~N}$} \\
\hline $\mathrm{THg} \sim \operatorname{Sex}+\delta^{13} \mathrm{C}+\delta^{15} \mathrm{~N}+\operatorname{Sex}: \delta^{15} \mathrm{~N}$ & 6 & 0.00 & 0.63 & 66.1 \\
\hline $\mathrm{THg} \sim \operatorname{Sex}+\delta^{13} \mathrm{C}+\delta^{15} \mathrm{~N}+\mathrm{Sex}: \delta^{13} \mathrm{C}+\mathrm{Sex}: \delta^{15} \mathrm{~N}$ & 7 & 2.22 & 0.21 & \\
\hline $\mathrm{THg} \sim \mathrm{Sex}+\delta^{13} \mathrm{C}$ & 4 & 4.70 & 0.06 & \\
\hline $\mathrm{THg} \sim \mathrm{Sex}+\delta^{13} \mathrm{C}+\mathrm{Sex}: \delta^{13} \mathrm{C}$ & 5 & 4.85 & 0.06 & \\
\hline
\end{tabular}

${ }^{a}$ Weights across all models sum to 1.00 (not all shown).

${ }^{b} \mathrm{We}$ did not consider an interaction between blood $\delta^{13} \mathrm{C}$ and $\delta^{15} \mathrm{~N}$ values. 
Table 3. Review of published blood total mercury ( $\mathrm{THg}$ ) concentrations ( $\mu \mathrm{g} \mathrm{g}^{-1} \mathrm{dw}$ ) in adults and chicks of large skua species in the Northern and Southern Hemispheres. Values are means \pm SDs.

\begin{tabular}{|c|c|c|c|c|c|c|}
\hline Skua species & $\begin{array}{l}\text { Sampling } \\
\text { year(s) }\end{array}$ & Age & $n$ & Breeding site & $\mathrm{THg}\left(\mu \mathrm{g} \mathrm{g}^{-1} \mathrm{dw}\right)$ & References \\
\hline \multicolumn{7}{|l|}{ Northern hemisphere } \\
\hline \multirow[t]{6}{*}{ Great skua Stercorarius skua } & 1996 & Chick & 27 & Foula, Shetland & $0.27 \pm 0.16$ & Bearhop et al. (2000c) \\
\hline & 1997 & Chick & 23 & St Kilda, Western Isles & $1.12 \pm 0.41$ & Bearhop et al. (2000c) \\
\hline & 1996 & Adult & 57 & Foula, Shetland & $3.49 \pm 1.83$ & Bearhop et al. (2000a) \\
\hline & 1996 & Adult & 28 & Foula, Shetland & $3.67 \pm 2.03$ & Bearhop et al. (2000c) \\
\hline & $1996-1997$ & Adult & 33 & St Kilda, Western Isles & $6.71 \pm 3.08$ & Bearhop et al. (2000a) \\
\hline & 1997 & Adult & 23 & St Kilda, Western Isles & $7.37 \pm 3.10$ & Bearhop et al. (2000c) \\
\hline \multicolumn{7}{|l|}{ Southern Hemisphere } \\
\hline \multirow{10}{*}{ Brown skua Stercorarius antarcticus lonnbergi } & 2011 & Chick & 10 & Kerguelen archipelago & $2.31 \pm 0.33$ & Carravieri et al. (2017) \\
\hline & 2011 & Chick & 10 & Kerguelen archipelago & $2.32 \pm 0.34$ & Renedo et al. (2020) \\
\hline & 2011 & Chick & 10 & Crozet archipelago & $1.66 \pm 1.20$ & Carravieri et al. (2017) \\
\hline & 2012 & Chick & 11 & Crozet archipelago & $1.81 \pm 1.19$ & Renedo et al. (2020) \\
\hline & 2011 & Chick & 10 & Amsterdam Island & $3.98 \pm 0.77$ & Carravieri et al. (2017) \\
\hline & 2011 & Chick & 10 & Amsterdam Island & $4.00 \pm 0.89$ & Renedo et al. (2020) \\
\hline & 2019 & Adult & 23 & Hope Bay, Antarctic Peninsula & $0.95 \pm 0.45$ & This study \\
\hline & 2014 & Adult & 28 & Signy Island, South Orkney Islands & $3.42 \pm 2.29$ & This study \\
\hline & 2014 & Adult & 31 & Bird Island, South Georgia & $4.47 \pm 1.10$ & This study \\
\hline & 2001 & Adult & 68 & Kerguelen archipelago & $8.22 \pm 1.98$ & Goutte et al. (2014) \\
\hline \multirow{4}{*}{ South polar skua Stercorarius maccormicki } & 2011 & Chick & 11 & Adélie Land, Antarctica & $0.51 \pm 0.1$ & Carravieri et al. (2017) \\
\hline & 2011-2012 & Chick & 9 & Adélie Land, Antarctica & $0.53 \pm 0.08$ & Renedo et al. (2020) \\
\hline & 2003-2005 & Adult & 76 & Adélie Land, Antarctica & $2.15 \pm 1.48$ & Goutte et al. (2014) \\
\hline & 2019 & Adult & 6 & Hope Bay, Antarctic Peninsula & $1.41 \pm 1.01$ & Mills, unpublished data \\
\hline
\end{tabular}




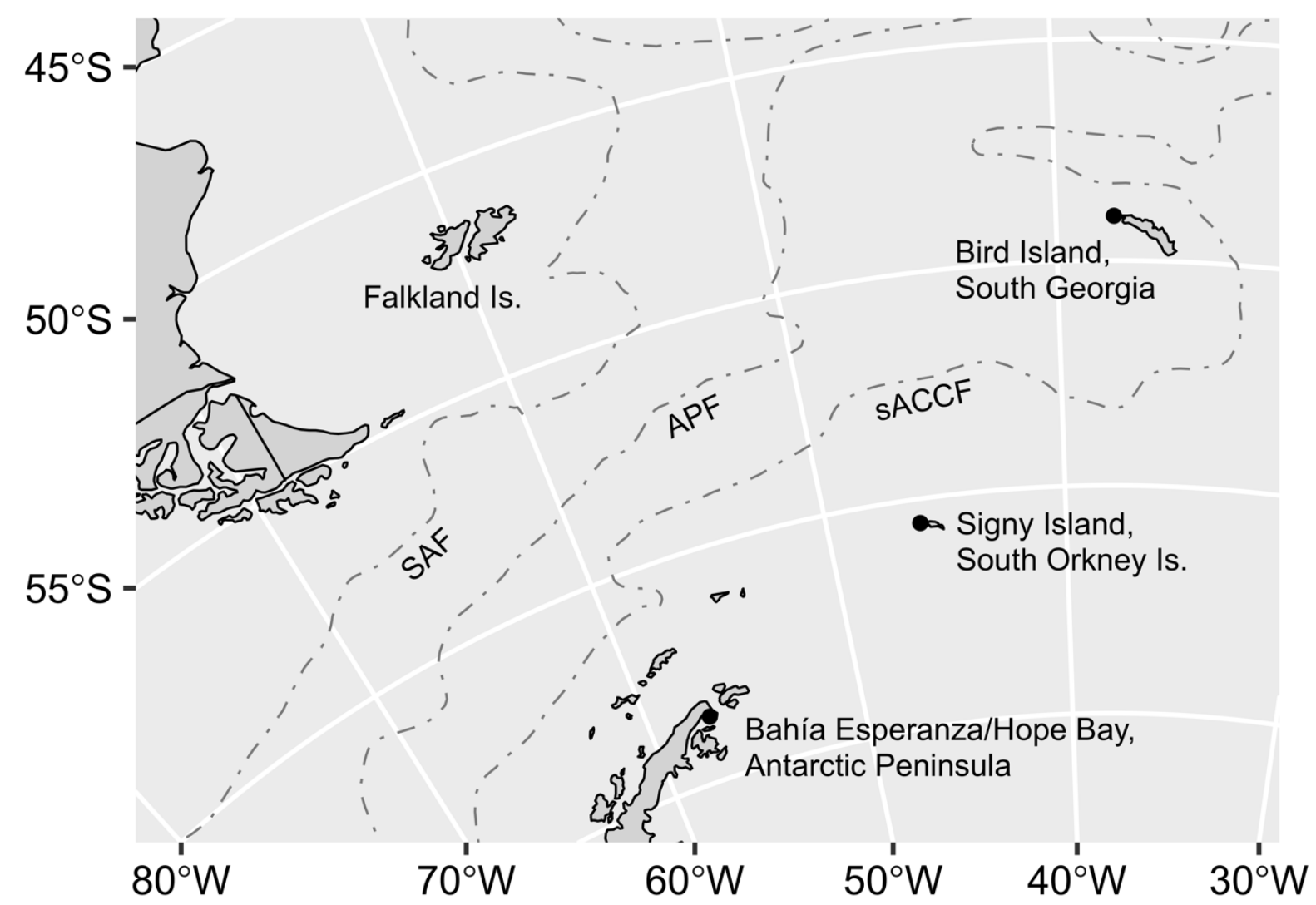

Figure 1. Location of the three study sites in relation to the Sub-Antarctic Front (SAF), the Antarctic Polar Front (APF) and the southern Antarctic Circumpolar Current Front (sACCF). The study sites are: (i) Bahía Esperanza/Hope Bay, Antarctic Peninsula (63⒉ $4^{\prime} \mathrm{S}, 5^{\circ} 01^{\text {’W}}$ ); (ii) Signy Island, South Orkney Islands $\left(60^{\circ} 43^{\prime} \mathrm{S}, 45^{\circ} 36^{\prime} \mathrm{W}\right)$; and (iii) Bird Island, South

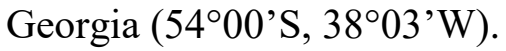




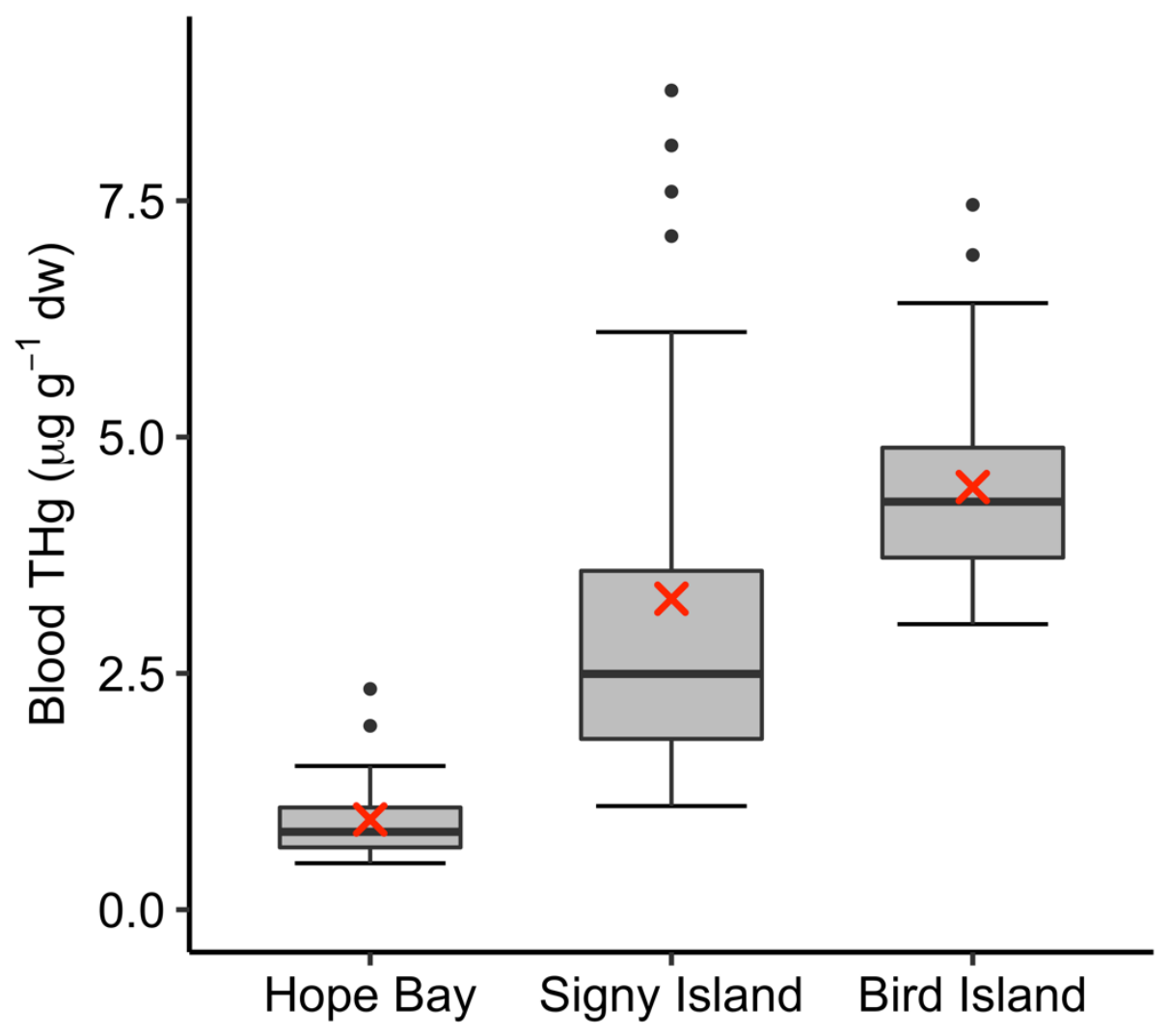

Figure 2. Box plots showing significant differences in the total mercury ( $\mathrm{THg}$ ) concentrations $\left(\mu \mathrm{g} \mathrm{g}^{-1} \mathrm{dw}\right)$ of red blood cells sampled from adult brown skuas Stercorarius antarcticus lonnbergi at: Bahía Esperanza/Hope Bay, Antarctic Peninsula $\left(63^{\circ} 24^{\prime} \mathrm{S}, 57^{\circ} 01^{\prime} \mathrm{W}\right)$; Signy

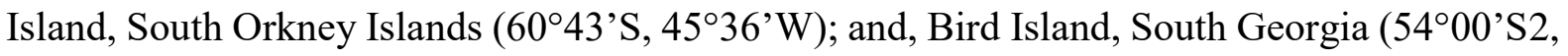
$\left.38^{\circ} 03^{\prime} \mathrm{W}\right)$. Red crosses are mean values. 

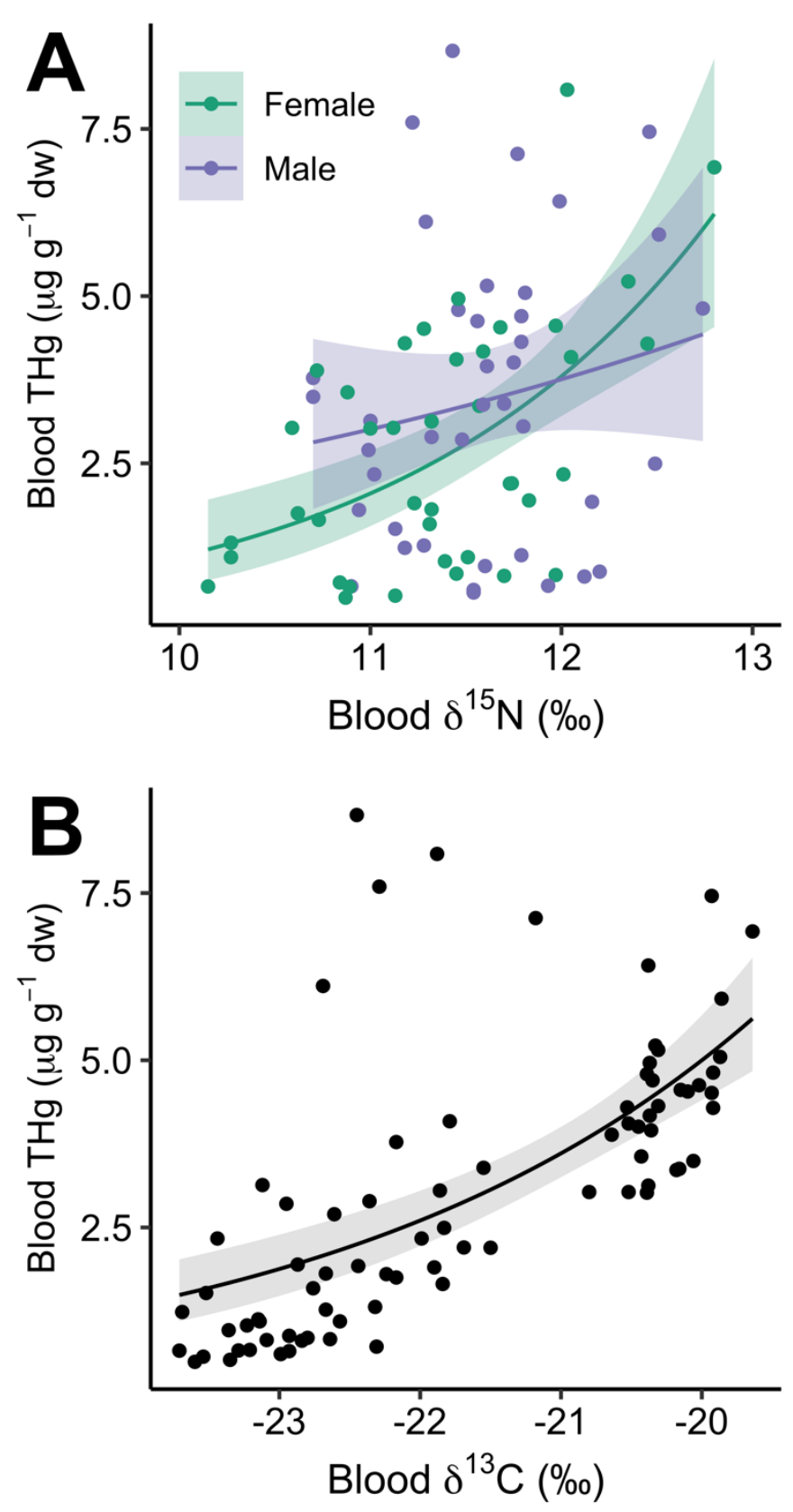

Figure 3. Relationships between total mercury (THg) concentrations ( $\mu \mathrm{g} \mathrm{g}^{-1} \mathrm{dw}$ ) and bulk stable isotope ratios of $(\mathbf{A})$ nitrogen $\left(\delta^{15} \mathrm{~N}\right)$, and $(\mathbf{B})$ carbon $\left(\delta^{13} \mathrm{C}\right)$ in red blood cells sampled from adult brown skuas Stercorarius antarcticus lonnbergi from three breeding colonies: Bahía

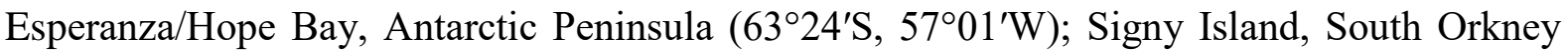
Islands $\left(60^{\circ} 43^{\prime} \mathrm{S}, 45^{\circ} 36^{\prime} \mathrm{W}\right)$; and, Bird Island, South Georgia ( $\left.54^{\circ} 00^{\prime} \mathrm{S} 2,38^{\circ} 03^{\prime} \mathrm{W}\right)$. 